\title{
GYTIS ORŽIKAUSKAS
}

Vilniaus Gedimino technikos universitetas, Lietuva

Vilnius Gediminas Technical University, Lithuania

\section{ARCHITEKTÜROS ORIGINALUMO SĄSAJOS SU LAIKO PROGRESO IDĖJA}

\author{
Connection between Originality of Architecture \\ and Idea of Time Progress
}

\section{SUMMARY}

This article examines the connection between the originality of architecture and the idea of time progress from the start of professional Western architecture to contemporary architecture. The Ancient Greeks already knew how to exploit traditional similitude or highlighted innovation in architecture in order to express the necessary cultural message. Architectural progress was no longer so important during medieval period, because Christian culture established a finite concept of time, according to which both past and future were equally revealed. The progress of architecture was spontaneous up until 17 th century, when the theory of architectural styles was established. During this period newly created retrospective architecture was considered to be equal to the architecture of past styles. However, at the beginning of 20th century architectural styles were diluted into one theory of decoration, which provoked the arrival of new uniform modernist architectural style. However, the theory of architectural styles is limited, because especially original architecture does not follow common established rules of architectural style. As such contemporary architecture must be evaluated by alternative concepts of progress, such as cyclic rotation of architectural trends and an established pluralism. Those circumstances are especially favorable for the rise of nonstandard architectural expression.

\section{SANTRAUKA}

Straipsnyje nagrinejjama architektūros originalumo sąsaja su laiko progreso idejja nuo Vakarų profesionaliosios architektūros pradžios iki šiuolaikinės architektūros. Jau senovės Graikijos architektūroje suvokta, kad naujai kuriamos architektūros pabrèžtina inovacija arba perteiktas tradicijų tęsinys gali būti išnaudotas reikiamai kultūrinei žiniai perteikti. Viduramžių architektūroje progresas laiko tėkmėje nustojo aktualumo, kadangi krikščioniškoji kultūra tikèjo baigtine laiko koncepcija su nulemta pradžia ir pabaiga. Architektū- 
ra organiškai plètojosi iki pat XVIII a., kai buvo suformuota architektūros stilių teorija. Šiuo laikotarpiu buvo įtikèta, kad naujai kuriama retrospektyvi architektūra gali lygiomis teisėmis atstovauti praejjusiems architektūros stiliams. Tačiau iki XX a. pr. plètota stilių raidos teorija visus istorinius architektūros stilius traktavo vienodai - kaip dekoro priemonę, i kurią buvo suformuotas reaktyvus, tačiau vienodas modernizmo stilius. Stilių raidos teorija yra ribota, kadangi itin originali, bendrų stiliaus nuostatų neatitinkanti architektūra lieka nęivertinta. Todèl šiuolaikinès architektūros progresas turi būti vertinamas alternatyviai: kaip cikliškos architektūros tendencijų kaitos bei vyraujančio kultūrinio daugybingumo apraiška. Šios sąlygos yra ypatingai palankios originaliai nestandartinei architektūros raiškai rastis.

\section{ARCHITEKTŪROS KONTEKSTUALUMO LAIKO ATŽVILGIU SAMPRATOS GENEZE்}

Architektūra yra erdvių formavimo menas, kuriam, kaip ir kitoms meno šakoms, būdinga nuolatinè meninių idejų pažanga. Būtent šis progresas dèl meninių idejju plètojimo gali būti ìvardintas pagrindiniu architektūros raidos veiksniu. Architektūros funkcija yra gana stabili konstanta: nors nuolat atsiranda naujos tipologijos pastatu, pačios pagrindinès pastatu funkcijos - gyvenamoji, ūkio, religinè, komercinè, edukacinè, valdžios ir administracinè, kariuomenès, transporto - atsirado jau seniausiais laikais. Funkcinių reikalavimų kaita ir technologiju plètra yra svarbūs šiuolaikinès architektūros raidos faktoriai. Technologiju plètros dinamika tokia stipri, kad galima patikèti, jog būtent ji verčia plètotis architektūros idejjas. Vis dèlto apžvelgdami visą architektūros raidą nuo seniausiujų laikų turime pripažinti, kad architektūros istorijoje technologijos ir pastatu infrastruktūra plètojosi ne taip dinamiškai, kaip dinamiškai keitėsi architektūros meninés idejjos. Tad architektūros pažanga turi būti vertinama ne kaip statybos technologiju, bet kaip architektūros meninès ittaigos veiksnys.

Pažanga yra laikoma viena pagrindinių meno egzistavimo sąlygų, - kaip teigè vokiečiu tapytojas ir meno profeso- rius Willi Baumeisteris (1889-1955): „Mene nėra geru konservatyvių krypčiu - visos tik pažangios: žmogus ir menininkas panašus i dviratininką. Sustojęs - virsta. ${ }^{\prime 1}$ Tai yra paradoksali ir dviprasmiška meno egzistavimo sąlyga, kadangi nors iš menininkų tikimasi sulaukti nematytu idèju, unikalūs meno kūriniai nepraranda aktualumo slenkant laikui ir nèra pamirštami. Dèl šios priežasties menas neišvengiamai yra laikiškai kontekstualus vertindami naują meno kūrini, lyginame jị su praeityje sukurtais. Architektūra taip pat reflektavo savo kontekstualumą laiko požiūriu jau pačioje profesionaliosios architektūros pradžioje. Architektūrologè Sophia Psarra savo tyrimuose atskleidè, kaip laiko suvokimas buvo pabrèžtas Atėnų akropolio architektūrinèje kompozicijoje. S. Psarra tyrimų objektas buvo pabrèžtinai skirtinga dvieju panašiu laiku statytu statiniu - Partenono ir Erechtejono - raiška. Partenonas yra dominuojantis aiškaus plano tradicinis simetriškas pastatas, o Erechtėjonas yra komplikuotos planinès struktūros kelių grindu lygių netaisyklingas pastatas - retas tokios klasikinès architektūros pavyzdys. Autorẻ atskleidè, kad šiuo dvieju ansamblio pastatu kontrastu buvo perteikta naujos santvarkos - demokratijos - viršenybès 
idejja ${ }^{2}$. Partenonas, priešingai nei paprastai manoma, nebuvo šventykla - jame iš tiesų nebuvo atliekami jokie religiniai ritualai, jis niekada neturèjo žynių, šventyklai būtinos įrangos ir kulto statulos ${ }^{3}$, pastatas neturejjo garbinimui reikalingo altoriaus. Erechtejjonas - atvirkščiai, buvo ne vienam dievui skirta šventykla, kuri turejjo kelis altorius ir mistines vietas bei kultinę tariamai ne žmogaus rankų padarytą medinę Aténės statula, kuriai Panatènaju procesija aukodavo austą rūbą ${ }^{4}$. S. Psarra teigia, kad Partenonas buvo statytas kaip politinis paminklas, kuriam suteikta reguliari, nusistovejjusi tradicinès graikų šventyklos forma. $\mathrm{O}$ Erechtejonui - tikrajai senojo kulto vietai - buvo suteikta netaisyklinga, moderni ir avangardiška forma. Tyrëja rašo, kad „atèniečiai Atènų akropolyje regejjo dabarties mistifikaciją ir praeities demistifikaciją: dabartis pavaizduota lyg sustingusios praeities formos, o praeitis tapo inovacija, gyvuojančia dabartyje. Partenonas idealizavo demokratiją ir Atènų imperinę galia, o Erechtèjonas, atvirkščiai, demonstravo, kad naujoji santvarka palaiko ivvairialypi tikejjimo kulta, praktikuojamą archajinio miesto isčiose. ${ }^{5}$ S. Psarra izžvalgas, kad senovès graikai jau mokejjo manipuliuoti naujos architektūros santykiu su laiko kontekstu - tiek tradicijomis, tiek inovacija - patvirtina amžininko, graikų klasiko Plutarcho (46-120) žodžiai: „Periklio kūrinys kelia didžiulę nuostabą: tie darbai baigti per trumpą laika, tačiau yra ilgalaikiai. Savo tobulybe kiekvienas pastatas jau tuomet atrodè senovinis; bet dèl savo šviežumo jie atrodo pastatyti ir pabaigti tik dabar. Taigi jų amžinas naujumas išgebëjo juos nuo laiko prisilietimo, tartum kūrèjas būtų suteikęs savo kūriniams amžiną jaunystę ir îkvėpęs jiems amžiną gyvybę"6.

Visiškai kitaip manipuliuoja laiku viduramžių architektūra. İsigalëjus krikščionybei, visuomenèje įsivyravo baigtinio laiko idejja. Krikščionys tikèjo, kad laikas yra tiesinè atkarpa, kurioje pradžios tašką žymi pasaulio sukūrimas, o pabaigą žymi apokalipsè. Šios atkarpos vidurio tašku laikyta Kristaus kančia ir nuodèmių atpirkimas, o abi laiko atkarpos dalys laikytos simetriškomis, todèl manyta, kad kiekvieną Senojo Testamento îvyki, asmenybę ar parabolę iki Kristaus atitiko Naujojo Testamento ivvykis, asmenybė ar palyginimas ${ }^{7}$. Tačiau kartu su tiesine laiko samprata egzistavo ir cikliško laiko koncepcija - Kristaus gimima, kančią ir prisikèlimą buvo privaloma išgyventi iš naujo per kiekvienus liturginius metus, kad šie ivvykiai realiu laiku gyvuotų tikinčiųju sąmonëje. Individas turèjo pasiekti roju per tris kartojamus sureikšmintus momentus - prasidejjimą, išganymą ir pasaulio pabaigą ${ }^{8}$. Dèl šios priežasties viduramžių bažnyčios ir katedros statytos savotiškame laiko vakuume, kada dabartis tapatinta tiek su praeitimi, tiek su būsima amžinybe. Sakralinių pastatų architektūroje aktualumą igavo naratyvios kompozicijos, iliustruojančios Kristaus istoriją. Krikščionims tiek praeities, tiek ateities ìvykiai atrodè žinomi, todèl idejjiniu lygmeniu akcentuoti naujos architektūros santykị su praeitimi ar pabrèžti inovacijas nebuvo svarbu.

Tokią kūrybinę intenciją geriausiai iliustruoja Pizos katedros Stebuklų lauko ansamblis. Pati Pizos katedra, statyta 1064 m., atitinka tradicinę griežtą bažnyčių orientaciją pasaulio šalių atžvilgiu, kai altorius tiksliai atgręžtas ị Rytus. Katedrą ir 1152 m. statytą krikštyklą jungia 
simetrijos ašis, tačiau kompleksą užbaigianti 1173-1372 m. statyta varpinè yra patraukta į šoną nuo bendros ansamblio simetrijos ašies. Dèl tuo metu galiojusio romėnu papročio kapines iškelti už miesto ribų Pizos katedra su numatytais palaidojimais buvo statyta atvirose pievose $^{9}$, todèl norint visus tris komplekso pastatus buvo galima be kliūčiu išdèstyti pagal vieną simetrijos aši. Išderintą kompoziciją galima paaiškinti tuo, jog Stebuklų lauko pastatai statyti prasikeičiantys tarpusavyje taip, kad lankytojas juos visus tris iš karto matytų vos iž̌engęs pro uždaro šventoriaus vartus. Šie trys pastatai akcentuoja svarbiausius žmogaus gyvenimo momentus: prasidèjima, išganymą ir gyvenimo pabaiga, kuriuos atitinka krikštykla, katedra ir varpinè (varpais skambinta per laidotuves). Lankytojas buvo tiesiog priverstas isisąmoninti šiuos tris aspektus, kadangi i Pizos katedrą buvo įleidžiama ne pro pagrindines, bet pro galines duris prie varpinès, todèl norintys patekti i bažnyčios vidu tikintieji turèjo pereiti visą šventoriaus teritoriją ir apžvelgti visus tris pagrindinius pastatus. Tačiau Pizos katedros ansamblio pastatai iliustruoja ne tik iprastą sekuliaru gyvenimo naratyvą. Žinoma, kad apvalainų Italijos krikštyklų forma buvo nusižiūrèta nuo antikos ir Karolingų laikų mauzoliejų. Toks paradoksalus faktas aiškintinas tuo, kad krikštas laikytas mistine mirtimi ir atgimimu Kristuje, kaip moke šv. Paulius. Krikštijama tuomet buvo ne bet kada, o tik tris kartus per metus, taip pat per Velykas - prisikèlimo šventę ${ }^{10}$. Savo ruožtu apvalios atskirai stovinčios varpinès nebuvo būdingos Italijos viduramžių architektūrai. Laikantis Senojo ir Naujojo Testamentu simetriškumo koncepcijos, teologas Bernardas Klervietis (1090-1153) èmè tapatinti Švč. Mergelę Mariją su Saliamono Giesmiu giesmejje apdainuota nuotaka, kurios kaklas lyginamas su dramblio kaulo bokštu. Todèl nuo XII a. Marijos visuotiniu ikonografiniu simboliu tapo dramblio kaulo bokštas ${ }^{11}$. Tik pastatyta Pizos katedra buvo konsekruota Švč. Mergelès Marijos Ėmimo i dangu vardu, todèl apvali balto marmuro Pizos katedros varpinè gali simbolizuoti tiek pačią Mergelę Marija, tiek (kaip raiški vertikalè) jos žengimą i dangų. Šiomis prasmèmis Pizos katedros pastatai perteikia kitą tiesinio laiko naratyvą apie sekuliarią mirtį ir atgimimą Kristuje (krikštykla), kančią (kryžiaus konfigūracijos katedra) ir žengimą i rojų (varpinè). Tokia savarankiška laiko samprata - kai gimimas ir mirtis yra pusiausvyrą sudarantys laiko momentai, issisąmoninta kaip vykstanti realiu laiku. Galime pažymèti, kad iki pat XIX a. bažnytinèje dailèje vaizduotos savo laiko, o ne Kristaus epochos rūbais vilkinčios asmenybès. Architektūroje tokią laiko sampratą iliustruoja tai, kad iki pat modernizmo laikotarpio skirtingu stiliu krikščionių bažnyčių architektūra buvo daugiau ar mažiau nusistovejjusi ir suformuota pagal tą patị modeli.

\section{ARCHITEKTŪROS STILIŲ PAŽANGOS TEORIJA}

Renesanso laikotarpio kultūroje vèl issisąmonintas santykis su praejjusių laikų kultūra - buvo iš naujo atsigrę̌zta i antikos humanizmo tradicijas. Vis dèlto 
krikščioniškosios viduramžių kultūros itaka galëjo lemti tai, kad beveik iki pat XVIII a. nebuvo aktualizuota savistaba, kokią vietą naujai kuriama architektūra užima laiko tèkmëje. Architektai kūrè šiuolaikiniu (t. y. to meto) stiliumi, todèl architektūros pažanga vyko organiškai. Viduramžiu architektūra tiesiog laikyta netobula, todèl architektūra vystėsi tobulëjant igūdžiams, žinioms ir technologijoms. Savistabos trūkumą iliustruoja tai, kad antikiniame Vitruvijaus traktate Dešimt knygu apie architektūra nurodytas architektūros skirstymas ị tvirtumą, naudingumą ir groži buvo aktualizuotas tiek viduramžių, tiek renesanso ir baroko architektūroje, tačiau nebuvo stebimasi, kodèl interpretuojant tą pati teorini šaltinį buvo pastatyta skirtingų stilių architektūra. Nebuvo suformuota ir pati architektūros stiliaus sąvoka. Šiai sąvokai atsirasti padejo Švietimo epochoje pradèti nuoseklūs istorinès architektūros tyrimai. Klasicizmo architektūroje iš naujo imta orientuotis i antikos laikotarpi, tačiau, kitaip nei renesanse, orientuotasi ne tik i idejjas, bet remtasi detaliomis graikų ir romėnu architektūros studijomis bei Pompèju archeologiniais tyrimais. Tyrinejjant praeityje kurtos architektūros raišką įsisąmoninta kaip „stiliai" arba alternatyvūs būdai ịpavidalinti architektūrą. Ilgainiui išnyko nuostata semtis ịkvejpimo tik iš antikos - sampratos lūžis ívyko tada, kai apie $1770 \mathrm{~m}$. Anglijos premjero sūnus Horace' as Walpole'as (1717-1797) nusprendè parodyti savo antikvarinius polinkius ir savo užmiesčio namą Stawberry Hill'e pasistate gotikos stiliumi ${ }^{12}$. Platesni istorinès architektūros tyrimai sudare prielaidą retrospektyviems ",atgimimo“ (angl. revival), arba neo-stiliams atsirasti, nes su- vokta galimybė orientuotis i platu praeities stiliu spektrą. Kai XIX a. architektūroje pradèjo vyrauti istorizmo stilius, atsirado ir architektūros stiliu raidos mokslas, aiškinantis, kaip nuosekliai iš vienų achitektūros formų vystėsi kitos architektūros formos. Stilių teorija buvo aktualizuota XIX a. anglu meno kritiko Johno Ruskino (1819-1900) 1851-1853 m. veikale Venecijos akmenys, taip pat vokiečiu meno teoretiku Carlo Friedricho von Rumohro (1785-1843), Gottfriedo Semperio (1803-1879), Alois Rieglio (18581905) darbuose ir tęsiama XX a. pradžioje vokiečiu meno istoriko Heinricho Wölfflino (1864-1945) ir čeku kilmès meno istoriko Paulo Franklo (1878-1962).

Ieškant nuorodu istorinejje architektūroje tikèta, kad pačius istorinius architektūros stilius galima tęsti. Pavyzdžiui, 1923 m. Lietuvoje išleistoje Kazimiero Jasėno knygoje Visuotine meno istorija. Architektūra teigta: „Klasicizmas, virtęs paskutinej savo evoliucijoj empiru, dingo kartu su galinguoju globẻju. Praūžus pragaištingu karų audrai, sukèlusiai tiek nesveikų, mirtingų dulkių ir paplūdusiai kraujo tvanais, niekas apie ji ir girdèti nebenorèjo. Tačiau augštesnieji luomai, akademijos ir mokslo vyrai antikès išsižadèti nemanè. Metę sausą ir kaulingą klasicizmą jie tikèjosi helenizme rasią idealą ir sutare grižti ị pirmapradị statymo būdą. <...> Taigi, šalin Romos išdidžių imperatorių stilių, šalin išdykusio uzurpatoriaus prasimanymus, teatgimsta gryna, sveika ir nemirtinga helenu statyba savo nedilstančiu grožiu! Deja, helenizmas apsigimè negyvèlis ir greitu laiku buvo palaidotas. Po $1850 \mathrm{~m}$. niekas juo statyti nebenorejo ir jis paskendo užuomaršos bangose. <...> Helos gyventojai jau senai miegojo amžinu miegu ir 
su jais dingo jų idealai, papročiai ir kultūra."13 Šiandieną net tobulai pakartota istorinè architektūra laikoma ne praejusio amžiaus kultūros, bet būtent šiuolaikinės architektūros pavyzdžiu, kadangi poreikis pastatyti retrospektyvų pastatą kilo dabartyje ir buvo veikiamas dabar vyraujančio architektūros suvokimo. Taip pat galime ivertinti, kad istorizmo architektūra daugeliu atžvilgių visiškai skiriasi nuo pasirinktų istorinès architektūros prototipų. Taip ìvyko dèl to, kad būtent nuo Apšvietos amžiaus - romantizmo laikotarpiu - buvo iškeltos vadinamosios ",architektūros sistemos" idejos ir teigta, jog visų senojo pasaulio kultūru - Egipto, Tarpupio, graiku ir romėnų, Bizantijos ir t. t. - architektūrą sudare trys dèmenys: konstrukcija, forma ir dekoracija ${ }^{14}$. Dèl tokio požiūrio visi istoriniai stiliai traktuoti kaip dekoras - išorinis kiautas, kuri galima „užmauti" ant reikiamos struktūros pastato. Toki požiūrị iliustruoja leisti architektūros katalogai, leidę užsakovui pasirinkti iš kelių alternatyvių to paties pastato stilių variantų. Visi istorizmo architektūros pastatai - kad ir kokie skirtingi jie atrodytų - iliustruoja tokią būtent XIX a. isivyravusią sampratą ir sukūrimo epochą. Remdamiesi šiuo pavyzdžiu galime teigti, kad nukrypti nuo tiesinès architektūros pažangos ir grižžti praktiškai yra neizmanoma.

Atsiribojimas nuo istorinių stilių ir pažangos idejja dar palyginti neseniai XX a. 1-7 dešimtmečiais - buvo pagrindinis naujos architektūros idejjinis pagrindas. Pavyzdžiui, vienas ryškiausių modernizmo architektūros atstovų Le Corbusier (1887-1965) 1929 m. vykusios paskaitos metu viešai perbraukè istorinės architektūros iliustracijas teigdamas, kad „tai - ne architektūra, tai - stiliai“. Savo 1923 m. knygoje Architektūros link jis rašè, kad „Liudviko XIV, XV ir XVI ar gotikos stiliai architektūrai ne daugiau kaip plunksna ant moters galvos: kartais gražu, bet ne visada ir ne kažkas daugiau"15. Šios pastabos rodo, kad dar XX a. pradžioje visa istorinė architektūra vis dar traktuota vienodai - kaip išorinès architektūros dekoracijos. Tokia skirtingu istorinių tradiciju samplaika $\mathfrak{i}$ vieną reiškinį buvo palanki tuo, kad modernizmas kurtas kaip reaktyvus, t. y. neigiantis, architektūros stilius. Sukurti prieštarą visam kaleidoskopui skirtingu kultūrinių tradicijų būtų buvę sudètinga, todèl buvo surastas bendras istorinès architektūros vardiklis - dekoras. Dekoras ir dailiųu menų ittaka itin aktualizuoti modernizmo architektūros teoretiku pareiškimuose, pvz., architektas Adolfas Loosas (1870-1933) 1908 m. paskelbè šūki "puošmenos - nusikaltimas"16, o 1978 m. Toronte vykusioje konferencijoje buvo svarstoma "skulptūros prieš architektūrą" tema su šūkiu: „Atsiriboti nuo architektūros - vienas iš visuomeninių dailès uždavinių! “17

Laiko pažangos sampratos atžvilgiu modernizmo teoretikai ivvede tiesini suvokimą su dvi atkarpas atskiriančiu lūžio tašku - istorinis laikotarpis iki modernizmo ir įsivyravęs modernizmas. Galbūt dèl tokio savarankiško kultūrinès raidos suvokimo modernizmo architektūros stilius buvo labiausiai aktualizuotas globalizmo kultūroje bei totalitariniuose režimuose. Modernizmo architektūra tiesiogine šio žodžio prasme turèjo įkūnyti pažangos idèją: architektūroje aktualizuota industrializacija, technizavimas, socialinè lygybė ir naujovès. Technologijų ir inovacijų raida buvo sutapatinta su 
architektūros meninės įtaigos raida. Juo inovatyvesnè atrodè architektūra, juo kokybiškesne ji buvo laikoma. Tačiau paradoksalu, kad statybu pažanga iš tiesu neturëjo sąsajų su architektūros originalumu, kadangi galiausiai globaliu mastu paplito unifikuota, nuspejjama ir nuobodi architektūra. Viena vertus, taip nutiko todèl, kad pats avangardo reiškinys yra ribotas - ilgainiui tai, kas nauja ir netikèta, tampa norma. Prabėgus kuriam laikui, modernizmo architektūra tapo visiškai nebenauja ir paaiškejjo, kad dalis vieninteliam kokybiniam kriterijui - nauju- mui - angažuotos architektūros nebeatrodo išskirtinės. Antra vertus, modernizmo teoretikai istorija, kurios reikèjo atsisakyti, suvokè ne kaip labai ìvairu, bet kaip stereotipizuotą reiškinį. Todèl kaip atsakas ị istorinę architektūrą buvo pasiūlytas tik vienas globaliu mastu paplitęs architektūrinès raiškos variantas - vadinamasis "tarptautinis stilius". Modernizmas buvo paskutinis architektūros stilius, kadangi po modernizmo sukurta architektūra priskiriama kryptims, nebe stiliams. Taip buvo baigta architektūros stilių pažangos samprata.

\section{PLIURALISTINĖ ŠIUOLAIKINĖS ARCHITEKTŪROS PAŽANGOS TEORIJA}

Alternatyvi architektūros stiliu pažangos teorija buvo pradèta dar XX a. pradžioje. Vokiečiu istorikas ir filosofas Oswaldas Spengleris (1880-1936) savo svarbiausiame veikale Vakaru saulèlydis pasiūlè kiekvieną kultūrą traktuoti kaip uždarą sistemą, kurioje architektūros stiliai sietini su filosofinio mąstymo pobūdžiu, matematika ir kt. Autoriaus manymu, kiekviena kultūra turi savo nepakartojamą stilių, kuris apima matematikos ypatybes, politinès valdžios tipus, dominuojančius menus ir architektūros formas ${ }^{19}$. O. Spenglerio veikalas buvo svarbus ir tuo, kad jame teigta, jog atskirų civilizacijų raida yra panaši ir vyksta pagal bendrus istorijos dèsnius. Tokios idejos sutapo su to meto architektūros teorijomis, kuriomis teigta, kad architektūros stiliu raidoje vyksta cikliška rotacija tarp racionaliu ir iracionaliu architektūros tendencijų. Šios tendencijos nebūtinai siejamos su konkrečiu vyraujančiu architektūros stiliumi, tačiau keli autoriai išgrynintoms racionalioms architektūros tendencijoms pavadinti vartojo subendrintą sąvoką "klasicizmas", o iracionalioms tendencijoms apibūdinti vartojo subendrintą sąvoką "barokas". Pavyzdžiui, prancūzų meno istorikas Henri Focillonas (1881-1943) 1934 m. knygoje Formu gyvenimas rašè, kad kiekvieno istorinio meno stiliaus evoliucija pereina keturias fazes: eksperimentu tarpsni, klasikos amžiu, perdirbimo ir baroko ${ }^{20}$. H. Wölfflinas teige, kad „Barokas ir klasika egzistuoja ne tik naujaisiais amžiais ir ne tik antikos architektūroje, bet ir tokioje svetimoje dirvoje kaip gotika. [...] Kiekvienas Vakaru Europos stilius, be savo klasikinès epochos, turèjo ir savo baroka, jeigu jam buvo duota laiko pastarajij išgyventi. [...] Vèlyvasis stilius pats savaime gali būti išreikštas kuo ìvairiausiais pavidalais, nes jo pradinè stadija tèra apribota tik bendriausia gyvybès forma." ${ }^{21}$ Jurgis Baltrušaitis (1903-1988) plètojo panašias idejjas teig- 
damas, kad Šumero menas turi organišką ir klasicizmo laikotarpì, Egipto Senosios karalystės architektūra „išdirba beveik visas vèlesnių klasikiniu statybų formules", tačiau "Saiso Imperija atgaivina [...] naują baroko formą"22, griežtą dorènini graiku orderi keitè plastinis jonėninis ir pikturalinis korintinis bei romėnų nesuvaržomas architektūrinis eklektiškumas, gotikos ekspresyvumą (vadinamaji flameboyant - „liepsnojančiosios" gotikos stilių) keitè Renesanso logika $^{23}$. Panašią idèją vèliau teigè postmodernizmo filosofas ir rašytojas Umberto Eco (1932-2016): „Kiekviena epocha, atskiras stilius turi savo postmodernizma, panašiai kaip kiekviena epocha gali turèti savajij manierizmą. Kiekvienas stilius prasideda avangardu ir baigiasi manierizmu (postmodernizmu). Avangardizmas pirmiausiai siekia sugriauti praeiti, deformuoja senas formas. Tačiau ateina toks laikas, kai avangardas (modernas) neturi kur toliau eiti ir vèl atsigręžiama i praeities vertybes, istorizmą ir meninès vertybès turi būti įvertintos iš naujo ${ }^{\prime 24}$, lygiai taip pat teigia postmodernizmo filosofas Wolfgangas Welschas (g. 1946). Savo knygoje Mūsu postmodernioji modernybe $\mathrm{W}$. Welschas tapatina postmodernizmo architektūrą su pliuralizmu ir aiškina, kad skirtingas architektūros kalbu kombinavimas (t. y. postmodernizmas) yra būdingas romėnų architektūrai, vèlyvojo baroko stiliaus Šv. Karlo bažnyčiai Vienoje ir architekto Karlo Friedricho Schinkelio (1781-1841) darbams ${ }^{25}$. Architektūros krypčiu raidoje pastebima cikliška rotacija, kai racionaliąsias architektūros tendencijas - klasikinę antikos architektūra, renesansa, klasicizmą ir modernizmą - keitè iracionaliosios architektūros tendencijos - helenizmas, vèlyvoji gotika, barokas, modernas (secesija, arba Art Noveau) ir postmodernizmas. Kiekviena naujesnè architektūros tendencija gimė kaip vẻlyvoji iš iprastu normu iškrypusi egzistavusios tendencijos atmaina, arba kaip nauja reakcija i prieš tai buvusią architektūros tendenciją. Architektūros originalumas gali būti traktuojamas kaip reakcija i prieš tai aktualizuotą raiškos formą.

Tokia cikliškos architektūros tendencijų kaitos teorija leidžia geriau ivvertinti neiprastas, vienetines architektūros raiškas. Architektūros stilių teorija yra grịsta raiškos bendrumu ir panašumu, todèl kūrëjai, netelpantys i̇ bendrus epochos rẻmus, architektūros istorijoje dažnai būdavo ignoruojami. Pavyzdžiui, slovėnų kilmės architekto Jože Plečniko (18721957) darbai pradèti vertinti tik po 1970uju todèl, kad jo kūryba nepritiko prie bendrų modernizmo stiliaus bruožų, o sui generis dailininkas ir architektas Friedensreichas Hundertwasseris (1928-2000) apskritai nèra vertinamas kokio nors architektūros stiliaus ar krypties kontekste. Ignoruoti ne tik pavieniai kūrejjai, bet ir konkretūs judèjimai, pavyzdžiui, įtakingas architektūros kritikas ir istorikas Sigfriedas Giedionas (1888-1968) 1941 m. išleistoje knygoje Erdvé, laikas ir architektūra. Naujos tradicijos augimas atmetè $X X$ a. I pusės ekspresionizmo architektūrą kaip „neadekvačią ${ }^{\prime 26}$, kadangi ji neturèjo sąsajų su modernizmo stiliumi. Tačiau nuo tiesinès stilių raidos atribota architektūros tendencijų teorija leidžia sieti originalias architektūros kryptis su platesniu kontekstu - pavyzdžiui, skirtingų laikotarpių romantizmo, moderno, ekspresionizmo ir futurizmo architektūra priskirtina tai pačiai iracionalizmo architektūros tendencijai. 
Kitas įsisąmonintas architektūros pažangos bruožas yra įsivyravęs architektūros pliuralizmas. Iki pat XVIII a. tuo pačiu metu formaliai galejo egzistuoti tik viena architektūrinès raiškos alternatyva. Kiekvienas naujas architektūros stilius organiškai pakeisdavo prieš tai buvusi vyko stilių rotacija. Tačiau romantizmo laikotarpiu, kada pradèta orientuotis ne tik $i$ antikos, bet ir $\mathfrak{i}$ kitus istorinius stilius, atsirado architektūros raiškos daugybingumas. Romantizmo architektūros kryptis (vèliau išsiplètojusi i istorizmo stilių) nepakeitè tuo metu vyravusio klasicizmo stiliaus - abi alternatyvos egzistavo kartu. Vèlesnè istorizmo stiliaus architektūra pati savaime buvo daugybinè: romantizmo laikotarpiu dar stengtasi išlaikyti daugiau ar mažiau vieningą būdingą pasirinkto istorinio stiliaus raiška, o istorizmo laikotarpiu buvo galima ne tik rinktis iš gausybès galimu pritaikyti istorinių stilių paletès, bet ir juos maišyti tarpusavyje - taip atsirado eklektikos architektūros kryptis. Vieningą architektūros raišką dar bandyta įdiegti moderno ir modernizmo architektūros stiliais. Tačiau modernizmo kultūrinis laikotarpis visuotinai baigèsi tada, kai buvo nustota tikèti, kad bet kuriai problemai spręsti egzistuoja vienas globalus būdas. Taip pat nustota manyti, kad kuri nors kultūrinè terpè, pasaulèžiūra ar idejja yra pranašesnè už kitas, ir visuotinai akcentuotas individualumas - prasidèjo postmodernizmo kultūrinis laikotarpis ${ }^{27}$. Iprasta manyti, kad postmodernizmo architektūra vyravo ne ilgiau nei XX a. 8-9 dešimtmečiai (Lietuvoje dešimtmečiu ilgau). Postmodernioji architektūra Lietuvoje vertinama prieštaringai - siejama tik su kičo, eklektikos ir dekoratyvumo apraiškomis ${ }^{28}$, moderniz- mo nuostatų neigimu, kitoniškumu ir klasikinès architektūros elementų skolinimusi ${ }^{29}$. Tačiau W. Welschas postmodernizmą architektūroje pirmiausia sieja su daugiakalbiškumu (t. y. daugiaformišku$\mathrm{mu}$ ), teigdamas, kad „Objektyviai nagrinèti daugiakalbę postmoderno architektūrą yra nepalyginamai sunkiau už vienakalbę. Daugybingumas trukdo dermei. Kita vertus, jis atveria duris - labai gaila - beatodairai. [...] Dažniausiai trokštamos ivairovès klaidos - kratinys ir disneilendiškumas. Kad tai šovimas pro šalị, nesunku pastebèti: juk beatodaira ìvairovės nedidina, o, priešingai, ją niveliuoja, nes gimdo abejingumą. [...] Kaip tik tai brèžia ribą tarp postmodernybès aukštos ir žemos prabos formų arba postmodernybès ir makalynès. “29

Šiuolaikinèje architektūroje koegzistuojanti skirtingų paralelių architektūros krypčiu gausa patvirtina W. Welscho įžvalgas. Ryškios šiuolaikinės architektūros kryptys yra dekonstruktyvizmas, aukštụjų technologiju architektūra (high-tech), blobizmas (bionika), brutalizmas, neomodernizmas (minimalizmas). Maža to, architektūra laiko požiūriu gali būti orientuota tiek i praeiti (tradicionalizmas, neoistorizmas ir neoklasicizmas), tiek i ateiti (ultra-moderni ir futurizmo architektūra). Toks daugybingumas yra pagrindinis besitęsiančios postmodernizmo kultūrinès terpès požymis. Lietuvos architektūros teorijoje nėra îprasta traktuoti, kad šiuolaikinès architektūros kryptis taip pat atstovauja postmodernizmui, tačiau tokia traktuote yra iprasta Vakarų architektūros teorijoje. Pavyzdžiui, dekonstruktyvizmo architektūros krypčiai atstovaujantys architektai Frankas O. Gehry (g. 1929), Peteris Eisenmanas (g. 1932), Bernardas Tschumi (g. 1944), 
Zaha Hadidas (1950-2016), Hiromi Fujii (g. 1932), Remas Koolhaasas (g. 1944), Danielis Libeskindas (g. 1946) ir Coop Himmelb(l)au architektu grupé (ikurta 1968 m.) yra nedviprasmiškai ịvardijami postmodernios architektūros kūrejjais ${ }^{30}$. Modernizmo stiliaus architektūra buvo vertinama pagal tai, kaip sukurtas pas-

\section{Literatūra ir nuorodos}

1 Wolfgang Welsch, Mūsu postmodernioji moderny$b \dot{e}$. Vertė Alfonsas Tekorius. Vilnius: Alma littera, 2004, p. 180.

2 Sophia Psarra, The Parthenon and the Erechtheion: the architectural formation of place, politics and myth, The Journal of Architecture 9, 2004, p. 100.

3 Mary Beard, The Parthenon. London: Profile Books, 2002, p. 45.

4 Sophia Psarra. Architecture and Narrative: The Formation of Space and Cultural Meaning. Routledge, 2009, p. 24.

5 Sophia Psarra, The Parthenon and the Erechtheion, p. 100.

6 Anatolijus Varšavskis, Perlu verinys. Vertė Irena Jašinskaitè. Vilnius: Vaga, 1982, p. 102.

7 Aronas Gurevičius, Viduramžiu kultūros kategorijos. Vertė Vanda Nekrašienè. Vilnius: Mintis, 1982, p. 117.

8 Ten pat, p. 101.

9 Leonardo Benevolo, Europos miesto istorija. Vertè Aušra Čižikienè. Vilnius: Baltos lankos, 1998, p. 34, 44-45.

10 Roger A. Stalely, Early Medieval Architecture. Oxford: Oxford University Press, 1999, p. 60.

11 Marcus Graham Bull, The Miracles of Our Lady of Rocamadour. Analysis and translation. Woodbridge: Boydell \& Brewer, 1999, p. 29.

12 Ernst Hans Gombrich, Meno istorija. Vertė Irena Jomantienè. Vilnius: Alma littera, 1995, p. 476-477.

13 Kazimieras Jasènas, Visuotine meno istorija I. Architektūra. Kaunas: Mintauja, 1923, p. 391-392.

14 Richard A. Etlin, Frank Lloyd Wright and Le Corbusier: The Romantic Legacy. Manchester and New York: Manchester University Press, 1994, p. 12-13. tatas atitiko bendras šio stiliaus nuostatas ir idejas, o šiuo metu vyraujantis architektūrinis daugybingumas leidžia atsiskleisti nestandartinèms idëjoms, kurios negali būti vertinamos šabloniškai iš vieno požiūrio taško. Tai yra pagrindinè šiuolaikinès architektūros originalumo sąlyga.

15 Ten pat.

16 Jonas Minkevičius, Architektūros kryptys užsienyje. Vilnius: Mintis, 1971, p. 7.

17 Juozas Adamonis, Nuo taško iki sintezès. Vilnius: Vilniaus dailès akademijos leidykla, 2008, p. 38.

18 Wolfgang Welsch, Mūsu postmodernioji modernybe, p. 304-305, 343-344.

19 Ten paat, p. 19-20.

20 Jurgis Baltrušaitis, Visuotine meno istorija I. Kaunas: Šviesa, 1992, p. 5.

21 Heinrich Wölfflin, Pamatinés meno istorijos savokos. Stiliaus raidos problema naujajame mene. Vertè Jurgita Liudavičienè. Vilnius: Pradai, 2000, p. 241-242.

22 Jurgis Baltrušaitis. Visuotine meno istorija I. Kaunas: Šviesa, 1992, p. 269.

23 Jurgis Baltrušaitis. Visuotine meno istorija II. Kaunas: Šviesa, 1992, p. 265-274.

24 Umberto Eco, Rožés vardas. Vertė Inga Tuliševskaitè. Vilnius: Alna, 1991, p. 105.

25 Wolfgang Welsch, Mūsu postmodernioji modernybe, p. 211, 215-220.

26 Sigfried Giedion, Space, Time and Architecture: The Growth of a New Tradition. Cambridge: Harvard University Press, 1967, p. 487.

27 Algimantas Mačiulis, Iracionalumo apraiškos XX a. užsienio ir Lietuvos architektūroje. Urbanistika ir architektūra 3(34), 2010, p. 156.

28 Vereta Rupeikaitè, Pernelyg susireikšminę pastatai rodo vertybių krizę. Kauno diena, 201103 14 , p. 12.

${ }^{29}$ Wolfgang Welsch, Mūsu postmodernioji modernybe, p. 24, 71.

30 Tim Woods, Beginning Postmodernism. Manchester and New York: Manchester University Press, 1999, p. 106. 